Review Article

\title{
Neutrophilic Inflammation in the Immune Responses of Chronic Obstructive Pulmonary Disease: Lessons from Animal Models
}

\author{
Gang Huang, ${ }^{1}$ Xu-Chen Xu, ${ }^{1}$ Jie-Sen Zhou, ${ }^{1}$ Zhou-Yang Li, ${ }^{1}$ Hai-Pin Chen, ${ }^{1}$ Yong Wang, \\ Wen Li, ${ }^{1}$ Hua-Hao Shen, ${ }^{1,2}$ and Zhi-Hua Chen ${ }^{1}$ \\ ${ }^{1}$ Department of Respiratory and Critical Care Medicine, Second Hospital of Zhejiang University School of Medicine, Hangzhou, \\ Zhejiang, China \\ ${ }^{2}$ State Key Lab of Respiratory Disease, Guangzhou, China
}

Correspondence should be addressed to Zhi-Hua Chen; zhihuachen2010@163.com

Received 31 January 2017; Accepted 5 April 2017; Published 27 April 2017

Academic Editor: Carlos Rosales

Copyright (c) 2017 Gang Huang et al. This is an open access article distributed under the Creative Commons Attribution License, which permits unrestricted use, distribution, and reproduction in any medium, provided the original work is properly cited.

\begin{abstract}
Chronic obstructive pulmonary disease (COPD) is a major cause of mortality worldwide, which is characterized by chronic bronchitis, destruction of small airways, and enlargement/disorganization of alveoli. It is generally accepted that the neutrophilic airway inflammation observed in the lungs of COPD patients is intrinsically linked to the tissue destruction and alveolar airspace enlargement, leading to disease progression. Animal models play an important role in studying the underlying mechanisms of COPD as they address questions involving integrated whole body responses. This review aims to summarize the current animal models of COPD, focusing on their advantages and disadvantages on immune responses and neutrophilic inflammation. Also, we propose a potential new animal model of COPD, which may mimic the most characteristics of human COPD pathogenesis, including persistent moderate-to-high levels of neutrophilic inflammation.
\end{abstract}

\section{Introduction}

Chronic obstructive pulmonary disease (COPD) is a major public health problem that is currently the fourth cause of death globally and affects about $10 \%$ of the adult population worldwide [1-3]. It is generally accepted that the neutrophilic inflammation observed in the lungs of COPD patients is intrinsically linked to the tissue destruction and alveolar airspace enlargement, leading to disease progression. Cigarette smoke injures epithelial cells and then releases "danger signals" which act as ligands for toll-like receptors (TLRs) in the epithelium. These actions contribute to the production of chemokines and cytokines, which results in an innate immunity. Products from the inflammatory cells may injure the extracellular matrix, leading to the release of TLR ligands and TLR activation, which in turn promote further inflammation and damage of lung parenchyma. Moreover, chronic cigarette smoke can induce an adaptive immune response, including $\mathrm{CD}^{+} \mathrm{T}$ cells, cytolytic $\mathrm{CD} 8^{+} \mathrm{T}$ cells, and $\mathrm{B}$ cells, leading to cellular necrosis and apoptosis, immune and complement deposition, tissue injury with airway remodeling, and emphysema [4]. Animal models act as a bridge between in vitro studies in the laboratory and studies in humans. As such, they have exerted a great impact on the investigation of many medical conditions. This review first gives an overview of the main experimental models of COPD to discuss their advantages and disadvantages in studying the neutrophilic inflammation in COPD and then try to propose a new, effective, and useful model.

\section{Protease-Induced Emphysema Models}

In 1965, Gross et al. [5] firstly proposed a model of pulmonary emphysema by instilling papain into trachea of rats. With the diagnosis of emphysema and the genetic deficiency of the protease inhibitor alpha-1-anti-trypsin [6], this animal 
TABLe 1: Acute tobacco smoke exposure.

\begin{tabular}{|c|c|c|c|}
\hline Treatment & Time & Response & Reference \\
\hline $\begin{array}{l}\text { Twice a day, } 1 \text { hour } \\
\text { per section, } 3 \text { days }\end{array}$ & 3 days & $\begin{array}{l}\text { The numbers of neutrophils and the levels of proinflammatory mediators, keratinocyte } \\
\text { chemoattractant (KC), macrophage inflammatory protein } 2 \text { (MIP-2), and interleukin } 1 \text { beta } \\
\text { (IL-1 } \beta) \text { are all increased in bronchoalveolar lavage fluid (BALF). }\end{array}$ & {$[26]$} \\
\hline $\begin{array}{l}\text { Twelve cigarettes a day, } \\
\text { three times a day }\end{array}$ & 5 days & $\begin{array}{l}\text { Acute exposure to cigarette smoke causes oxidative stress and increases the counts of } \\
\text { leukocytes and macrophages and the levels of several proinflammatory cytokines, such as } \\
\text { tumor necrosis factor alpha (TNF- } \alpha \text { ), IL-1 } \beta \text {, interleukin } 6 \text { (IL-6), and KC. }\end{array}$ & [27] \\
\hline $\begin{array}{l}\text { Twenty cigarettes a day, } \\
\text { four times a day }\end{array}$ & 7 days & $\begin{array}{l}\text { Acute exposure to cigarette smoke increases the number of total cells, neutrophils, } \\
\text { macrophages, and lymphocytes in BALF and increases the levels of KC and monocyte } \\
\text { chemotactic protein } 1 \text { (MCP-1). }\end{array}$ & {$[28]$} \\
\hline Five cigarettes a day & 3 days & $\begin{array}{l}\text { The numbers of mobilizing neutrophils and differentiating macrophages are significantly } \\
\text { increased in BALF, and the levels of IL- } 1 \beta \text {, IL-6, interferon gamma (IFN- } \gamma \text { ), TNF- } \alpha \text {, and } \\
\text { MCP-1 in BALF and lung are also increased. }\end{array}$ & [29] \\
\hline
\end{tabular}

model provided the basis for the proteinase-anti-proteinase hypothesis of human emphysema. According to this theory, various proteases, such as porcine pancreatic elastase, papain, or neutrophil elastase [7-9], have been subsequently instilled into trachea to test for the function to induce emphysema in animals. After intratracheal protease instillation, airway inflammation in the lung parenchyma, airspace enlargement, and pulmonary dysfunction (such as air trapping, alveolar destruction, and increased lung volume) have been observed $[10,11]$. These features are similar to human emphysema although the speed of occurrence and development is drastically increased.

There are a number of protocols for the induction of emphysema by proteases. Authors have shown that the severity of the protease-induced emphysema is related to the dosage and frequency of the protease [12]. In a murine model, the damage caused by protease persists after 4 weeks of administration, and the application of repeated doses can result in severe cases of the disease [13-15].

Protease-induced emphysema models have a number of advantages, such as simple operation, inexpensive, and high efficiency. The characteristics similar to COPD appear quickly compared to other methods [13], such as the use of cigarette smoke. Moreover, the severity of disease depends on the dosage and frequency of the enzyme, and protease-induced emphysema is related to the epithelial and endothelial cell apoptosis, extracellular matrix degradation, and presence of oxidative stress, which make it suitable to study every phase in emphysema and to investigate neutrophilic inflammation in COPD. Other interesting aspects of this model are that it can reproduce various features of the human disease [16-18], especially the morphology of the lung parenchyma destruction, and that the induced morphological and functional changes are detectable for a long time.

Generally, it takes quite a long time for the development of COPD in human. Despite that the model reproduces many characteristics of human emphysema, this protease-induced emphysema model does not mimic a continuous low-level inflammatory process, especially the adaptive helper $\mathrm{T}$ cell immune responses induced by tobacco smoke, which is the most risk factor of COPD. This model neither provides the exact mechanism of alveolar destruction and the sequence of pathological events [17].

\section{Tobacco Smoke-Induced Emphysema Models}

Tobacco smoke is the most risk factor for COPD [19]. Epidemiology studies demonstrate that the incidence of COPD in smokers is higher than that in nonsmokers. Exposure to tobacco smoke can continuously induce inflammation (inflammatory cell influx and increases of cytokines and chemokines in the airway and parenchyma), mucus hypersecretion (goblet cell metaplasia), emphysema (alveolar enlargement and increased lung volume), airway remodeling (smooth muscle deposition, matrix deposition, and fibrosis), and lung dysfunction [20]. Thus, the use of tobacco smokeinduced animal models can reproduce the real process in the development of COPD, especially for investigating the pathophysiological mechanisms.

Since Huber et al. [21] have firstly described a detailed study regarding smoke-induced emphysema in animals, there are a wide variety of exposure protocols for this model. Using tobacco smoke-induced model with single, multiple, or chronic exposure regimes can have different insights into the disease pathology. Acute tobacco smoke exposure (Table 1) has been demonstrated the presence of inflammatory infiltrate in the pulmonary parenchyma (the increased number of inflammatory cells and cytokines) [22], whereas chronic exposure (Table 2) probably provides the most similar animal model of human COPD because it induces disease (emphysema, epithelial cell metaplasia, airway remodeling, and decline in lung function) with the same stimulus, rather than just inflammation [23]. At present, there are two major exposure modes, whole-body smoke exposure [24] and nose-only smoke exposure [25].

Smoke-induced animal models of emphysema can not only reproduce the pathological process in the development of COPD but also provide the opportunity to test the effect of viral or bacterial infection in the presence of emphysema development which contributes to the acute exacerbation of COPD. Meshi et al. [33] have found that in guinea pigs, chronic cigarette smoke exposure caused lesions similar to human centrilobular emphysema and that latent adenoviral 
TABle 2: Chronic tobacco smoke exposure.

\begin{tabular}{|c|c|c|c|}
\hline Treatment & Time & Response & Reference \\
\hline $\begin{array}{l}\text { Four cigarettes a day, } \\
5 \text { days a week }\end{array}$ & 6 months & $\begin{array}{c}\text { Both Th1 and Th17 cells are significantly increased, and the levels of IL-6 and IL-17 } \\
\text { are also increased. }\end{array}$ & {$[30]$} \\
\hline $\begin{array}{l}\text { Twelve cigarettes a day, } \\
5 \text { days a week }\end{array}$ & 6 months & $\begin{array}{c}\text { An increase in the total number of inflammatory cells and macrophages in } \\
\text { BALF of mice exposed to cigarette smoke. The release of IL-1 } \beta \text { and TNF- } \alpha \text { is } \\
\text { increased as well. }\end{array}$ & {$[31]$} \\
\hline $\begin{array}{l}\text { Four times a day, } \\
5 \text { minutes per section, } \\
5 \text { days a week }\end{array}$ & 4 months & $\begin{array}{c}\text { Functional IL-17A protein secreted in the lung likely establishes an autocrine } \\
\text { loop that further induces TH17 differentiation, thereby exacerbating the effect } \\
\text { of smoke-induced TH1 and TH17 inflammation in the lungs. }\end{array}$ & [32] \\
\hline
\end{tabular}

infection combined with cigarette smoke exposure caused an excess increase in lung volume, air-space volume, and lung weight and a further decrease in surface-to-volume ratio compared with smoke exposure alone. In addition, tobacco smoke exposure faithfully recapitulates the predominant lung $\mathrm{TH} 1$ and $\mathrm{TH} 17$ responses that have previously been demonstrated as the characteristic of human emphysema. Thus, this model is suitable for studying COPD pathogenesis, especially for the $\mathrm{T}$ cell immunity.

Despite the smoke-induced animal models of emphysema are widely accepted worldwide, they still have a lot of disadvantages [23]. Firstly, the model is time- and energyconsuming (about 6 months). Secondly, there is no uniform standard for exposure method, since the dose, time, and animal strains may lead to different conclusions with same stimulator. Thirdly, the airway inflammation in this model is weak and the mucus expression is not obvious, which is not suitable to study about the mechanisms, especially for the neutrophilic inflammation in COPD [23]. The major limitation of this methodology, however, is the fact that even the COPD patients have left the smoking habit, the progression of disease still occurs. In experimental models, this phenomenon is not observed, since the end of exposure results in stable and nonprogressive emphysema [34]. Furthermore, species and strain differences must be taken into consideration when selecting an appropriate model. For instance, it appears that guinea pigs will acquire vascular alterations with smoke that are not found in standard rat models $[35,36]$.

\section{Chemical Drug-Induced Airway Inflammation Models}

Authors have found that various kinds of chemical drugs could induce inflammation and emphysema in pulmonary parenchyma, including lipopolysaccharides (LPS) [37], cadmium chloride, sulfur dioxide, and so on.

4.1. LPS-Induced Models. LPS is a major proinflammatory glycolipid component in the gram-negative bacterial cell wall. It can present as a contaminant on airborne particles and exist in cigarette smoke and air pollution. A single large dose of LPS instillation causes an inflammatory response that is combination with mucus hypersecretion and bronchoconstriction [38, 39], which mimic acute exacerbations, either given alone or given to animals also receiving cigarette smoke.
Long-term usage of bacterial LPS alone or together with short periods of exposure to cigarette smoke can induce emphysema in animals. For instance, a hamster emphysema model induced by installation of LPS twice per week for 4 weeks produced enlarged air spaces and remodeled airways with thickened walls and increased goblet cells. These changes resemble human emphysema and small airway remodeling [40].

4.2. Cadmium-Induced Models. Several reports have suggested that cadmium chloride $(\mathrm{CdCl} 2)$ can reproduce experimental emphysema in animals [41, 42]. A few days after $\mathrm{CdCl} 2$ instillation, it causes an increase in vascular permeability with enhanced migration of polymorphonuclear leucocytes (PMN) and macrophages. Polymorphonuclear leucocyte recruitment plays an important role in enhancing inflammatory process and impairing the oxidant-antioxidant balance. Moreover, proinflammatory cytokines, such as matrix metalloprotease (MMP), are also related to cadmium-induced emphysema [43-45]. Kirschvink et al. [46] have shown that cadmium-induced emphysema in rats is dependent of pulmonary inflammation as well as of MMP production, as the increased MMP-2 and MMP-9 production contributes to the development of emphysema.

4.3. Sulfur Dioxide-Induced Models. As an irritant gas, sulfur dioxide can melt in water and become $\mathrm{H}_{2} \mathrm{SO}_{3}$ after intratracheal inhalation. $\mathrm{H}_{2} \mathrm{SO}_{3}$ can damage airway epithelium, and chronic exposure of rats to high concentrations of $\mathrm{SO}_{2}$ gas causes lesions similar to those seen in human chronic bronchitis. Shore et al. [47] have found that rats exposed to 250 ppm $\mathrm{SO}_{2}$ gas, 5 hours a day, 5 days a week, for a period of 4 weeks caused a small but significant increase in pulmonary resistance (RL) and a decrease in dynamic compliance (Cdyn). Kodavanti et al. [48] have shown that $\mathrm{SO}_{2}$-induced model could produce emphysema and bronchitis similar to human COPD through pulmonary function test.

COPD is a chronic pathological process, and the accumulation of neutrophils and macrophages in trachea can contribute to airway remodeling, which causes ventilatory disorder gradually [49]. Chemical drug-induced airway inflammation model can only mimic lesions of airway and pulmonary parenchyma in COPD rather than reproduce the chronic pathological process, and these models are not recommended for investigation of COPD pathogenesis. However, the airway inflammation in this model is strong enough and the observed inflammatory and pathologic 
TABLE 3: Natural mutant emphysema models.

\begin{tabular}{lcc}
\hline Mouse and gene & Phenotypes & Reference \\
\hline Beige (Bg) & Impaired alveolar septation because of its deficiency in endosome biogenesis & [51, 52] \\
Blotchy (Blo) & Disruption of elastic fibers & [53] \\
Pallid (Pa) & Progressive emphysema because of increased collagen degradation & [54] \\
Tight skin (Tsk +/-) & Airspace enlargement because of impaired alveolar septation. Mice also have lower & serum elastase inhibitory capacity
\end{tabular}

TABLE 4: Knockout mutant emphysema models.

\begin{tabular}{|c|c|c|}
\hline Mouse and gene & Phenotypes & Reference \\
\hline $\begin{array}{l}\text { Tissue inhibitor of } \\
\text { metalloproteinases-3 (TIMP-3) }\end{array}$ & $\begin{array}{l}\text { Progressive emphysema from two weeks old with evidence of collagen degradation } \\
\text { and increased MMP activity }\end{array}$ & {$[56,57]$} \\
\hline Surfactant protein D (SP-D) & $\begin{array}{c}\text { Progressive airspace enlargement with } 3 \text { weeks of life. Increased macrophages with } \\
\text { activated MMPs. The gene influences the response of alveolar epithelial type II cells } \\
\text { to the injurious events }\end{array}$ & {$[58,59]$} \\
\hline Lysosomal acid lipase (LAL) & $\begin{array}{l}\text { LAL is a key enzyme in the metabolic pathway of neutral lipids. Areas of alveolar destruction } \\
\text { because of neutrophil influx, foamy macrophages, and Clara cell hypertrophy }\end{array}$ & {$[60,61]$} \\
\hline Klotho & Klotho is an "antiageing" hormone and transmembrane protein & {$[62]$} \\
\hline Integrin beta-6 (Itgb6) & Inhibition of TGF- $\beta$ signaling causes increased expression of MMP-12 by macrophages. & {$[63]$} \\
\hline $\begin{array}{l}\text { Gamma retinoic acid receptor } \\
(\mathrm{RAR} \gamma)\end{array}$ & Airspace enlargement because of impaired alveolar septation & {$[64,65]$} \\
\hline $\begin{array}{l}\text { Platelet-derived growth factor A } \\
\text { (PDGF-A) }\end{array}$ & $\begin{array}{l}\text { Impaired alveolar septa lake of tropoelastin expression and lack lung alveolar } \\
\text { smooth muscle cells }\end{array}$ & {$[66]$} \\
\hline $\begin{array}{l}\text { Growth factor receptor } 3 \text { and } \\
4(\text { GFR } 3-4)\end{array}$ & Absence of secondary alveoli & {$[67]$} \\
\hline Fibulin-5/DANCE & $\begin{array}{l}\text { It is a secreted extracellular matrix protein that functions as a scaffold for elastin fiber } \\
\text { assembly. The model is due to the interruption of elastin synthesis }\end{array}$ & {$[68,69]$} \\
\hline Elastin & Deficient formation of air sacs & {$[70]$} \\
\hline $\begin{array}{l}\text { Tumor-necrosis alpha-converting } \\
\text { enzyme (TACE) }\end{array}$ & Disabled saccular structures & {$[71]$} \\
\hline Adenosine deaminase & Increased adenosine levels impair alveolar septation and induce inflammation & {$[72,73]$} \\
\hline POD-1 & Hypoplastic lungs & [74] \\
\hline
\end{tabular}

changes mimic those observed in human subjects with COPD, suggesting that this murine model could be applicable to dissect the role of inflammation in the pathogenesis of these disease conditions.

\section{Genetic Models}

Epidemiology studies have found that not all smokers are equally susceptible to toxicants (toxic particles and gases, mostly tobacco smoke) and only a percentage of them develop the disease. Another interesting aspect of observation is that COPD shows familial aggregation, suggesting that the genetic background of the smoker is a key element for COPD development $[4,50]$. According to the importance of gene, various studies produced emphysema models using either naturally occurring mouse strains or laboratoryproduced animals that either overexpress or knock out particular genes (Tables 3-5). We summarized briefly herein their types, advantages, and disadvantages.
Genetically altered animals can not only allow research of the effects of a specific gene/protein on almost all different anatomic lesions of COPD but also potentially be useful in designing therapeutic agents. In order to link genetic predisposition and environmental factors, genetic models have also been used in combination with cigarette smoke exposure to mimic the natural condition of the onset of COPD [82, 83].

However, different mouse strains have a variety of genetic differences and they correspond to the phenotype of extreme monogenic individuals that probably does not adequately reproduce the most common forms of COPD, thus presenting limitations in terms of the translation of the results to the human disease $[84,85]$. Moreover, genetic operation is a difficult and lengthy process, since the inactivation of a gene sometimes causes lethal effects and in some cases do not produce a phenotype due to overlapping functional gene [86, 87]. In view of this point, pulmonary cell specifically genetic alternations are highly encouraged to demonstrate the function of a specific gene in COPD pathogenesis. In addition, the studies of genetically altered animals usually focus on 
TABLE 5: Overexpression mutant emphysema models.

\begin{tabular}{|c|c|c|}
\hline Mouse and gene & Phenotype & Reference \\
\hline Metalloproteinase-1 (MMP-1) & Progressive airspace enlargement because of degradation of collagen type III & [75] \\
\hline Placenta growth factor (PLGF) & $\begin{array}{l}\text { PLGF is an erythroblast-secreted factor. Airspace enlargement because of increased } \\
\text { alveolar epithelial cell apoptosis }\end{array}$ & {$[76,77]$} \\
\hline Interleukin-13 (IL-13) & Increased MMP and cathepsin expression leading to emphysema & {$[78]$} \\
\hline Interferon gamma $(\mathrm{IFN}-\gamma)$ & $\begin{array}{l}\text { Progressive emphysema and increased lung compliance. Increased expression of } \\
\text { MMPs, cathepsins, and caspases }\end{array}$ & {$[79,80]$} \\
\hline Tumor necrosis factor alpha (TNF- $\alpha$ ) & Nonprogressive emphysema after 1-3 months of life & {$[81]$} \\
\hline
\end{tabular}

the different anatomic lesions in mouse lung rather than the chronic pathological process, so that these animal models may be inappropriate to study the neutrophilic inflammation in COPD.

\section{Emphysema Models Based on Autoimmunity}

Some COPD patients never have cigarette smoking, and the abnormal inflammatory response in patients does not resolve after quitting smoking. Furthermore, recent advances in our understanding of disease pathogenesis indicate that COPD patients exhibit many of the same features as patients suffering from classical autoimmune diseases. For instance, COPD is typified by familial predilections, the frequent presence of systemic abnormalities, and the persistence of intrapulmonary inflammation (and clinical progression) despite removal of the stimulant (e.g., tobacco smoke) [88]. In general, these observations suggest that in some patients, the pathogenesis of COPD may involve an autoimmune component that contributes to the enhanced and persistent inflammatory response [88]. It has been shown that the presence of lymphoid aggregates rich in $\mathrm{T}$ and $\mathrm{B}$ cells correlated with the severity of airflow obstruction in COPD. Also, in these patients, infiltrating $\mathrm{CD}^{+}$cell counts were related to the severity of emphysema, airway flow limitation, and the increased apoptotic epithelial and endothelial cells [89]. It has also been shown that the $\mathrm{CD}^{+}{ }^{+} \mathrm{INF}-\gamma$ producing cells were related to the degree of airway obstruction [90], and that the $\mathrm{CD} 4^{+} \mathrm{T}$ cells from smokers with emphysema showed a Th17 profile, as they were able to secrete IL-17A [91]. According to the significant role of autoimmunity in progressive emphysema, Taraseviciene-Stewart et al. [92] have found that nude rats injected intraperitoneally with human umbilical vein endothelial cells (HUVECs) could produce an antibody against ECs (anti-EC humoral response), which subsequently leads to the influx of CD4 lymphocytes into the lung, apoptosis of alveolar septal cells, activation of MMPs, and eventual emphysema. In 2007, these authors also used CSE (cigarette smoke extract) intraperitoneal injection instead of xenogeneic endothelial cells to induce emphysema, and they hypothesized that CSE could act as an antigen triggering an immune response as well as oxidative stress that induced emphysema [93]. These models can reproduce emphysema, however, they use xenogeneic cells and external antigen, which cannot mimic the real pathogenesis regarding homologous autoimmunity in COPD patients. Moreover, Lee et al. have shown that the lung extracellular matrix proteins elastin, collagen, and decorin can be auto-antigen that induces the occurrence and development of COPD $[94,95]$. This exciting new breakthrough may open new avenues for developing effective animal models of COPD.

\section{Conclusion and a Perspective}

As summarized above, a variety numbers of animal models have been created to attempt to reproduce human COPD, but there are still some controversial and divergent aspects regarding some methodological variables in these models. There is no model that can totally mimic the whole features in human COPD at present. Also, the lack of golden standard whether the model has been built successfully makes it difficult to analyze conclusions from different models. Thus, it is important to establish a useful and effective model which can highly mimic the human COPD characteristics.

An ideal animal model of COPD should be induced by cigarette smoke or other pathogens related to human disease, with persistent moderate-to-high levels of neutrophilic airway inflammation, typical $\mathrm{T}$ cell immune responses, clearly evidenced mucus hyperproduction, progressed destruction of the lung parenchyma eventually leading to epithelial apoptosis and airspace enlargement, and declined lung functions, and if possible, less time and energy-consuming.

Given the fact that cigarette smoke-induced COPD could be a Th1/Th17 predominant autoimmune disease, and there should be certain self-antigens mediate such an autoimmune adaptive response, we propose here a novel emphysema model by referencing to a standard allergen-induced asthma model $[96,97]$. For such a model, we should first find the effective self-antigen which is likely produced in the lungs by cigarette smoke exposure and mediates the COPD autoimmune response. With this self-antigen, we may sensitize the mice and challenge the mice to build up an adaptive immune response model, likely exhibiting a high level of neutrophilic airway inflammation and a Th1/Th17 predominant immune response. It will be more appreciated if this model could clearly display a mucus hyperproduction as in the allergen-induced asthma model. If this could be realized, then a long-time self-antigen challenge should lead to the airway remodeling and emphysema-like airspace enlargement and eventually result in declined lung function, as does by allergens in the models of asthmatic airway remodeling [98, 99].

Nevertheless, a perfect animal model should provide a wide range of information on the pathophysiology of COPD 
and, as a consequence, support the development of new therapeutic approaches, resulting in a better quality of life for patients. Also, it should help us to understand more and better about the underlying mechanisms in COPD pathogenesis.

\section{Conflicts of Interest}

The authors declare that there is no conflict of interests regarding the publication of this paper.

\section{Authors' Contributions}

Gang Huang and $\mathrm{Xu}-\mathrm{Chen} \mathrm{Xu}$ wrote the manuscript. Jie-Sen Zhou, Zhou-Yang Li, Hai-Pin Chen, Yong Wang, and Wen Li participated in the preparation of the manuscript and discussion. Hua-Hao Shen and Zhi-Hua Chen supervised the work.

\section{Acknowledgments}

This work was supported by the General Projects (81370142 and 81670031 to Zhi-Hua Chen) from the National Natural Science Foundation of China, the Key Science-Technology Innovation Team of Zhejiang Province (2011R50016), and project from the National Clinical Research Center of China for Respiratory Disease.

\section{References}

[1] S. Reardon, "U. N. summit on noncommunicable diseases. Meeting brings attention but little action on chronic diseases," Science, vol. 333, no. 6049, p. 1561, 2011.

[2] A. D. Lopez, K. Shibuya, C. Rao et al., "Chronic obstructive pulmonary disease: current burden and future projections," The European Respiratory Journal, vol. 27, no. 2, pp. 397412, 2006.

[3] R. A. Pauwels and K. F. Rabe, "Burden and clinical features of chronic obstructive pulmonary disease (COPD)," Lancet, vol. 364, no. 9434, pp. 613-620, 2004.

[4] M. G. Cosio, M. Saetta, and A. Agusti, "Immunologic aspects of chronic obstructive pulmonary disease," The New England Journal of Medicine, vol. 360, no. 23, pp. 2445-2454, 2009.

[5] P. Gross, E. A. Pfitzer, E. Tolker, M. A. Babyak, and M. Kaschak, "Experimental emphysema: its production with papain in normal and silicotic rats," Archives of Environmental Health, vol. 11, no. 1, pp. 50-58, 1965.

[6] C. B. Laurell and S. Eriksson, "The electrophoretic alpha1globulin pattern of serum in alpha1-antitrypsin deficiency. 1963," COPD, vol. 10, Supplement 1, pp. 3-8, 2013.

[7] S. D. Shapiro, "Animal models for COPD," Chest, vol. 117, no. 5, Supplement 1, pp. 223s-227s, 2000.

[8] A. Janoff, "Elastases and emphysema. Current assessment of the protease-antiprotease hypothesis," The American Review of Respiratory Disease, vol. 132, no. 2, pp. 417-433, 1985.

[9] R. M. Senior, H. Tegner, C. Kuhn, K. Ohlsson, B. C. Starcher, and J. A. Pierce, "The induction of pulmonary emphysema with human leukocyte elastase," The American Review of Respiratory Disease, vol. 116, no. 3, pp. 469-475, 1977.

[10] M. V. Oliveira, S. C. Abreu, G. A. Padilha et al., "Characterization of a mouse model of emphysema induced by multiple instillations of low-dose elastase," Frontiers in Physiology, vol. 7, no. 457, p. 457, 2016.

[11] P. D. Kaplan, C. Kuhn, and J. A. Pierce, "The induction of emphysema with elastase. I. The evolution of the lesion and the influence of serum," The Journal of Laboratory and Clinical Medicine, vol. 82, no. 3, pp. 349-356, 1973.

[12] M. Kawakami, Y. Matsuo, K. Yoshiura, T. Nagase, and N. Yamashita, "Sequential and quantitative analysis of a murine model of elastase-induced emphysema," Biological \& Pharmaceutical Bulletin, vol. 31, no. 7, pp. 1434-1438, 2008.

[13] N. Longhini-Dos-Santos, V. A. Barbosa-de-Oliveira, R. H. Kozma et al., "Cell therapy with bone marrow mononuclear cells in elastase-induced pulmonary emphysema," Stem Cell Reviews, vol. 9, no. 2, pp. 210-218, 2013.

[14] C. J. Otto-Verberne, A. A. Ten Have-Opbroek, C. Franken, J. Hermans, and J. H. Dijkman, "Protective effect of pulmonary surfactant on elastase-induced emphysema in mice," The European Respiratory Journal, vol. 5, no. 10, pp. 12231230, 1992.

[15] L. Luthje, T. Raupach, H. Michels et al., "Exercise intolerance and systemic manifestations of pulmonary emphysema in a mouse model," Respiratory Research, vol. 10, no. 1, p. 7, 2009.

[16] M. Fujita and Y. Nakanishi, "The pathogenesis of COPD: lessons learned from in vivo animal models," Medical Science Monitor, vol. 13, no. 2, pp. Ra19-Ra24, 2007.

[17] T. H. March, F. H. Green, F. F. Hahn, and K. J. Nikula, "Animal models of emphysema and their relevance to studies of particle-induced disease," Inhalation Toxicology, vol. 12, Supplement 4, pp. 155-187, 2000.

[18] M. A. Antunes and P. R. Rocco, "Elastase-induced pulmonary emphysema: insights from experimental models," Anais da Academia Brasileira de Ciências, vol. 83, no. 4, pp. 13851396, 2011.

[19] F. Kheradmand, M. Shan, C. Xu, and D. B. Corry, "Autoimmunity in chronic obstructive pulmonary disease: clinical and experimental evidence," Expert Review of Clinical Immunology, vol. 8, no. 3, pp. 285-292, 2012.

[20] J. L. Wright and A. Churg, "Animal models of cigarette smoke-induced COPD," Chest, vol. 122, Supplement 6, pp. 301s-306s, 2002.

[21] G. L. Huber, P. Davies, G. R. Zwilling et al., "A morphologic and physiologic bioassay for quantifying alterations in the lung following experimental chronic inhalation of tobacco smoke," Bulletin Européen de Physiopathologie Respiratoire, vol. 17, no. 2, pp. 269-327, 1981.

[22] G. Caramori, P. Kirkham, A. Barczyk, A. Di Stefano, and I. Adcock, "Molecular pathogenesis of cigarette smokinginduced stable COPD," Annals of the new York Academy of Sciences, vol. 1340, no. 1, pp. 55-64, 2015.

[23] H. Zheng, Y. Liu, T. Huang, Z. Fang, G. Li, and S. He, "Development and characterization of a rat model of chronic obstructive pulmonary disease (COPD) induced by sidestream cigarette smoke," Toxicology Letters, vol. 189, no. 3, pp. 225234, 2009.

[24] S. P. Cendon, C. Battlehner, G. Lorenzi Filho et al., "Pulmonary emphysema induced by passive smoking: an experimental study in rats," Brazilian Journal of Medical and Biological Research, vol. 30, no. 10, pp. 1241-1247, 1997.

[25] M. Rinaldi, K. Maes, S. De Vleeschauwer et al., "Long-term nose-only cigarette smoke exposure induces emphysema and 
mild skeletal muscle dysfunction in mice," Disease Models \& Mechanisms, vol. 5, no. 3, pp. 333-341, 2012.

[26] C. A. Lerner, W. Lei, I. K. Sundar, and I. Rahman, "Genetic ablation of CXCR2 protects against cigarette smoke-induced lung inflammation and injury," Frontiers in Pharmacology, vol. 7, no. 391, p. 391, 2016.

[27] E. Kennedy-Feitosa, R. T. Okuro, V. Pinho Ribeiro et al., "Eucalyptol attenuates cigarette smoke-induced acute lung inflammation and oxidative stress in the mouse," Pulmonary Pharmacology \& Therapeutics, vol. 41, pp. 11-18, 2016.

[28] K. H. Jung, H. Beak, S. Park et al., "The therapeutic effects of tuberostemonine against cigarette smoke-induced acute lung inflammation in mice," European Journal of Pharmacology, vol. 774, pp. 80-86, 2016.

[29] D. Wang, K. Tao, J. Xion et al., "TAK-242 attenuates acute cigarette smoke-induced pulmonary inflammation in mouse via the TLR4/NF-kappaB signaling pathway," Biochemical and Biophysical Research Communications, vol. 472, no. 3, pp. 508-515, 2016.

[30] X. Yuan, M. Shan, R. You et al., "Activation of C3a receptor is required in cigarette smoke-mediated emphysema," Mucosal Immunology, vol. 8, no. 4, pp. 874-885, 2015.

[31] A. C. Toledo, R. M. Magalhaes, D. C. Hizume et al., "Aerobic exercise attenuates pulmonary injury induced by exposure to cigarette smoke," The European Respiratory Journal, vol. 39, no. 2, pp. 254-264, 2012.

[32] M. Shan, X. Yuan, L. Z. Song et al., "Cigarette smoke induction of osteopontin (SPP1) mediates $\mathrm{T}(\mathrm{H}) 17$ inflammation in human and experimental emphysema," Science Translational Medicine, vol. 4, no. 117, p. 117ra119, 2012.

[33] B. Meshi, T. Z. Vitalis, D. Ionescu et al., "Emphysematous lung destruction by cigarette smoke. The effects of latent adenoviral infection on the lung inflammatory response," American Journal of Respiratory Cell and Molecular Biology, vol. 26, no. 1, pp. 52-57, 2002.

[34] A. Churg, D. D. Sin, and J. L. Wright, "Everything prevents emphysema: are animal models of cigarette smoke-induced chronic obstructive pulmonary disease any use?" American Journal of Respiratory Cell and Molecular Biology, vol. 45, no. 6, pp. 1111-1115, 2011.

[35] J. L. Wright and A. Churg, "Cigarette smoke causes physiologic and morphologic changes of emphysema in the guinea pig," The American Review of Respiratory Disease, vol. 142, no. 6, Part 1, pp. 1422-1428, 1990.

[36] J. L. Wright, H. Tai, and A. Churg, "Vasoactive mediators and pulmonary hypertension after cigarette smoke exposure in the guinea pig," Journal of Applied Physiology (1985), vol. 100, no. 2, pp. 672-678, 2006.

[37] P. A. Dawkins and R. A. Stockley, "Animal models of chronic obstructive pulmonary disease," Thorax, vol. 56, no. 12, pp. 972-977, 2001.

[38] M. R. Starkey, A. G. Jarnicki, A. T. Essilfie et al., "Murine models of infectious exacerbations of airway inflammation," Current Opinion in Pharmacology, vol. 13, no. 3, pp. 337344, 2013.

[39] S. Kobayashi, R. Fujinawa, F. Ota et al., "A single dose of lipopolysaccharide into mice with emphysema mimics human chronic obstructive pulmonary disease exacerbation as assessed by micro-computed tomography," American Journal of Respiratory Cell and Molecular Biology, vol. 49, no. 6, pp. 971-977, 2013.
[40] A. Rudolphus, J. Stolk, J. H. Dijkman, and J. A. Kramps, “Inhibition of lipopolysaccharide-induced pulmonary emphysema by intratracheally instilled recombinant secretory leukocyte proteinase inhibitor," The American Review of Respiratory Disease, vol. 147, no. 2, pp. 442-447, 1993.

[41] M. L. Rubio, M. V. Sanchez-Cifuentes, G. Peces-Barba, S. Verbanck, M. Paiva, and N. Gonzalez Mangado, "Intrapulmonary gas mixing in panacinar- and centriacinar-induced emphysema in rats," American Journal of Respiratory and Critical Care Medicine, vol. 157, no. 1, pp. 237-245, 1998.

[42] A. G. Davison, P. M. Fayers, A. J. Taylor et al., "Cadmium fume inhalation and emphysema," Lancet, vol. 1, no. 8587, pp. 663-667, 1988.

[43] F. R. Frankel, J. R. Steeger, V. V. Damiano, M. Sohn, D. Oppenheim, and G. Weinbaum, "Induction of unilateral pulmonary fibrosis in the rat by cadmium chloride," American Journal of Respiratory Cell and Molecular Biology, vol. 5, no. 4, pp. 385-394, 1991.

[44] S. H. Gavett and G. Oberdorster, "Cadmium chloride and cadmium metallothionein-induced pulmonary injury and recruitment of polymorphonuclear leukocytes," Experimental Lung Research, vol. 20, no. 6, pp. 517-537, 1994.

[45] R. R. Bell, V. K. Nonavinakere, and M. R. Soliman, "Intratracheal exposure of the guinea pig lung to cadmium and/or selenium: a histological evaluation," Toxicology Letters, vol. 114, no. 1-3, pp. 101-109, 2000.

[46] N. Kirschvink, G. Vincke, L. Fievez et al., "Repeated cadmium nebulizations induce pulmonary MMP-2 and MMP-9 production and emphysema in rats," Toxicology, vol. 211, no. 1-2, pp. 36-48, 2005.

[47] S. Shore, L. Kobzik, N. C. Long et al., "Increased airway responsiveness to inhaled methacholine in a rat model of chronic bronchitis," American Journal of Respiratory and Critical Care Medicine, vol. 151, no. 6, pp. 19311938, 1995.

[48] U. P. Kodavanti, M. C. Jackson, A. D. Ledbetter et al., "The combination of elastase and sulfur dioxide exposure causes COPD-like lesions in the rat," Chest, vol. 117, no. 5, Supplement 1, pp. 299s-302s, 2000.

[49] J. Vestbo, S. S. Hurd, A. G. Agusti et al., "Global strategy for the diagnosis, management, and prevention of chronic obstructive pulmonary disease: GOLD executive summary," American Journal of Respiratory and Critical Care Medicine, vol. 187, no. 4, pp. 347-365, 2013.

[50] J. C. Hogg, F. Chu, S. Utokaparch et al., "The nature of smallairway obstruction in chronic obstructive pulmonary disease," The New England Journal of Medicine, vol. 350, no. 26, pp. 2645-2653, 2004.

[51] M. D. Barbosa, Q. A. Nguyen, V. T. Tchernev et al., "Identification of the homologous beige and Chediak-Higashi syndrome genes," Nature, vol. 382, no. 6588, pp. 262-265, 1996.

[52] P. Chatterjee, R. K. Tiwari, S. Rath, V. Bal, and A. George, "Modulation of antigen presentation and B cell receptor signaling in B cells of beige mice," Journal of Immunology, vol. 188, no. 6, pp. 2695-2702, 2012.

[53] A. C. McCartney, B. Fox, T. A. Partridge et al., "Emphysema in the blotchy mouse: a morphometric study," The Journal of Pathology, vol. 156, no. 1, pp. 77-81, 1988.

[54] M. Yoshida, S. Sakiyama, K. Kenzaki et al., "Functional evaluation of pallid mice with genetic emphysema," Laboratory Investigation, vol. 89, no. 7, pp. 760-768, 2009. 
[55] Y. Adachi, H. Oyaizu, S. Taketani et al., "Treatment and transfer of emphysema by a new bone marrow transplantation method from normal mice to Tsk mice and vice versa," Stem Cells, vol. 24, no. 9, pp. 2071-2077, 2006.

[56] K. Brew and H. Nagase, "The tissue inhibitors of metalloproteinases (TIMPs): an ancient family with structural and functional diversity," Biochimica et Biophysica Acta, vol. 1803, no. 1, pp. 55-71, 2010.

[57] E. L. Martin, E. A. Truscott, T. C. Bailey et al., "Lung mechanics in the TIMP3 null mouse and its response to mechanical ventilation," Experimental Lung Research, vol. 33, no. 2, pp. 99-113, 2007.

[58] S. E. Wert, M. Yoshida, A. M. LeVine et al., "Increased metalloproteinase activity, oxidant production, and emphysema in surfactant protein D gene-inactivated mice," Proceedings of the National Academy of Sciences of the United States of America, vol. 97, no. 11, pp. 5972-5977, 2000.

[59] C. Muhlfeld, J. Madsen, R. M. Mackay et al., "Effect of irradiation/bone marrow transplantation on alveolar epithelial type II cells is aggravated in surfactant protein D deficient mice," Histochemistry and Cell Biology, vol. 147, no. 1, pp. 49-61, 2017.

[60] X. Lian, C. Yan, L. Yang, Y. Xu, and H. Du, "Lysosomal acid lipase deficiency causes respiratory inflammation and destruction in the lung," American Journal of Physiology. Lung Cellular and Molecular Physiology, vol. 286, no. 4, pp. L801-L807, 2004.

[61] T. Zhao, X. Ding, H. Du, and C. Yan, "Lung epithelial cellspecific expression of human lysosomal acid lipase ameliorates lung inflammation and tumor metastasis in $\operatorname{Lipa}(-/-)$ mice," The American Journal of Pathology, vol. 186, no. 8, pp. 2183-2192, 2016.

[62] M. S. Patel, A. V. Donaldson, A. Lewis et al., "Klotho and smoking-an interplay influencing the skeletal muscle function deficits that occur in COPD," Respiratory Medicine, vol. 113, pp. 50-56, 2016.

[63] D. G. Morris, X. Huang, N. Kaminski et al., "Loss of integrin alpha(v)beta6-mediated TGF-beta activation causes Mmp12dependent emphysema," Nature, vol. 422, no. 6928, pp. 169173, 2003.

[64] S. McGowan, S. K. Jackson, M. Jenkins-Moore, H. H. Dai, P. Chambon, and J. M. Snyder, "Mice bearing deletions of retinoic acid receptors demonstrate reduced lung elastin and alveolar numbers," American Journal of Respiratory Cell and Molecular Biology, vol. 23, no. 2, pp. 162-167, 2000.

[65] M. Hind, J. Corcoran, and M. Maden, "Temporal/spatial expression of retinoid binding proteins and RAR isoforms in the postnatal lung," American Journal of Physiology. Lung Cellular and Molecular Physiology, vol. 282, no. 3, pp. L468-L476, 2002.

[66] P. Lindahl, L. Karlsson, M. Hellstrom et al., "Alveogenesis failure in PDGF-A-deficient mice is coupled to lack of distal spreading of alveolar smooth muscle cell progenitors during lung development," Development, vol. 124, no. 20, pp. 39433953, 1997.

[67] E. E. Morrisey and B. L. Hogan, "Preparing for the first breath: genetic and cellular mechanisms in lung development," Developmental Cell, vol. 18, no. 1, pp. 8-23, 2010.

[68] T. Nakamura, P. R. Lozano, Y. Ikeda et al., "Fibulin-5/DANCE is essential for elastogenesis in vivo," Nature, vol. 415, no. 6868 , pp. 171-175, 2002.
[69] P. P. Kuang, R. H. Goldstein, Y. Liu, D. C. Rishikof, J. C. Jean, and M. Joyce-Brady, "Coordinate expression of fibulin-5/ DANCE and elastin during lung injury repair," American Journal of Physiology. Lung Cellular and Molecular Physiology, vol. 285, no. 5, pp. L1147-L1152, 2003.

[70] D. P. Wendel, D. G. Taylor, K. H. Albertine, M. T. Keating, and D. Y. Li, "Impaired distal airway development in mice lacking elastin," American Journal of Respiratory Cell and Molecular Biology, vol. 23, no. 3, pp. 320-326, 2000.

[71] W. Xu, C. Liu, V. Kaartinen et al., "TACE in perinatal mouse lung epithelial cells promotes lung saccular formation," American Journal of Physiology. Lung Cellular and Molecular Physiology, vol. 305, no. 12, pp. L953-L963, 2013.

[72] M. R. Blackburn, J. B. Volmer, J. L. Thrasher et al., "Metabolic consequences of adenosine deaminase deficiency in mice are associated with defects in alveogenesis, pulmonary inflammation, and airway obstruction," The Journal of Experimental Medicine, vol. 192, no. 2, pp. 159-170, 2000.

[73] M. R. Blackburn and R. E. Kellems, "Adenosine deaminase deficiency: metabolic basis of immune deficiency and pulmonary inflammation," Advances in Immunology, vol. 86, pp. 1-41, 2005.

[74] S. E. Quaggin, L. Schwartz, S. Cui et al., "The basic-helix-loophelix protein pod1 is critically important for kidney and lung organogenesis," Development, vol. 126, no. 24, pp. 57715783, 1999.

[75] T. Shiomi, Y. Okada, R. Foronjy et al., "Emphysematous changes are caused by degradation of type III collagen in transgenic mice expressing MMP-1," Experimental Lung Research, vol. 29, no. 1, pp. 1-15, 2003.

[76] P. N. Tsao, Y. N. Su, H. Li et al., “Overexpression of placenta growth factor contributes to the pathogenesis of pulmonary emphysema," American Journal of Respiratory and Critical Care Medicine, vol. 169, no. 4, pp. 505-511, 2004.

[77] M. S. Eiymo Mwa Mpollo, E. B. Brandt, S. K. Shanmukhappa et al., "Placenta growth factor augments airway hyperresponsiveness via leukotrienes and IL-13," The Journal of Clinical Investigation, vol. 126, no. 2, pp. 571-584, 2016.

[78] T. Zheng, Z. Zhu, Z. Wang et al., "Inducible targeting of IL-13 to the adult lung causes matrix metalloproteinase- and cathepsin-dependent emphysema," The Journal of Clinical Investigation, vol. 106, no. 9, pp. 1081-1093, 2000.

[79] Z. Wang, T. Zheng, Z. Zhu et al., "Interferon gamma induction of pulmonary emphysema in the adult murine lung," The Journal of Experimental Medicine, vol. 192, no. 11, pp. 1587-1600, 2000.

[80] B. J. Lee, H. G. Moon, T. S. Shin et al., "Protective effects of basic fibroblast growth factor in the development of emphysema induced by interferon-gamma," Experimental \& Molecular Medicine, vol. 43, no. 4, pp. 169-178, 2011.

[81] B. R. Vuillemenot, J. F. Rodriguez, and G. W. Hoyle, "Lymphoid tissue and emphysema in the lungs of transgenic mice inducibly expressing tumor necrosis factor-alpha," American Journal of Respiratory Cell and Molecular Biology, vol. 30, no. 4, pp. 438-448, 2004.

[82] R. Vlahos, S. Bozinovski, R. C. Gualano, M. Ernst, and G. P. Anderson, "Modelling COPD in mice," Pulmonary Pharmacology \& Therapeutics, vol. 19, no. 1, pp. 12-17, 2006.

[83] C. S. Stevenson and M. A. Birrell, "Moving towards a new generation of animal models for asthma and COPD with 
improved clinical relevance," Pharmacology \& Therapeutics, vol. 130, no. 2, pp. 93-105, 2011.

[84] J. C. Fox and M. F. Fitzgerald, "Models of chronic obstructive pulmonary disease: a review of current status," Drug Discovery Today: Disease Models, vol. 1, no. 3, pp. 319-328, 2004.

[85] J. Van der Velden and K. J. Snibson, "Airway disease: the use of large animal models for drug discovery," Pulmonary Pharmacology \& Therapeutics, vol. 24, no. 5, pp. 525-532, 2011.

[86] R. M. Baron, A. J. Choi, C. A. Owen, and A. M. Choi, "Genetically manipulated mouse models of lung disease: potential and pitfalls," American Journal of Physiology. Lung Cellular and Molecular Physiology, vol. 302, no. 6, pp. L485-L497, 2012.

[87] Y. Zhang, "Applications of gene targeting in the investigations of human airway diseases," Cloning and Transgenesis, vol. 2, no. 1, p. 103, 2013.

[88] A. Agusti, W. MacNee, K. Donaldson, and M. Cosio, "Hypothesis: does COPD have an autoimmune component?" Thorax, vol. 58, no. 10, pp. 832-834, 2003.

[89] F. Calabrese, C. Giacometti, B. Beghe et al., "Marked alveolar apoptosis/proliferation imbalance in end-stage emphysema," Respiratory Research, vol. 6, no. 1, p. 14, 2005.

[90] A. K. Sullivan, P. L. Simonian, M. T. Falta et al., "Oligoclonal CD4+ T cells in the lungs of patients with severe emphysema," American Journal of Respiratory and Critical Care Medicine, vol. 172, no. 5, pp. 590-596, 2005.

[91] Y. Chang, J. Nadigel, N. Boulais et al., "CD8 positive T cells express IL-17 in patients with chronic obstructive pulmonary disease," Respiratory Research, vol. 12, no. 1, p. 43, 2011.

[92] L. Taraseviciene-Stewart, R. Scerbavicius, K. H. Choe et al., "An animal model of autoimmune emphysema," American Journal of Respiratory and Critical Care Medicine, vol. 171, no. 7, pp. 734-742, 2005.

[93] L. Taraseviciene-Stewart, D. Kraskauskas, J. Lee et al., "Cigarette smoke extract (CSE)-induced emphysema in mice," American Journal of Respiratory and Critical Care Medicine, vol. 175, p. A529, 2007.

[94] S. H. Lee, S. Goswami, A. Grudo et al., "Antielastin autoimmunity in tobacco smoking-induced emphysema," Nature Medicine, vol. 13, no. 5, pp. 567-569, 2007.

[95] C. A. Brandsma, W. Timens, M. Geerlings et al., "Induction of autoantibodies against lung matrix proteins and smokeinduced inflammation in mice," BMC Pulmonary Medicine, vol. 10, no. 1, p. 64, 2010.

[96] J. J. Lee, D. Dimina, M. P. Macias et al., "Defining a link with asthma in mice congenitally deficient in eosinophils," Science, vol. 305, no. 5691, pp. 1773-1776, 2004.

[97] B. P. Tian, W. Hua, L. X. Xia et al., "Exogenous interleukin17A inhibits eosinophil differentiation and alleviates allergic airway inflammation," American Journal of Respiratory Cell and Molecular Biology, vol. 52, no. 4, pp. 459-470, 2015.

[98] H. Movassagh, L. Shan, A. Mohammed, A. J. Halayko, and A. S. Gounni, "Semaphorin 3E deficiency exacerbates airway inflammation, hyperresponsiveness, and remodeling in a mouse model of allergic asthma," Journal of Immunology, vol. 198, no. 5, pp. 1805-1814, 2017.

[99] Z. H. Yu, J. R. Xu, Y. X. Wang et al., "Targeted inhibition of KCa3.1 channel attenuates airway inflammation and remodeling in allergic asthma," American Journal of Respiratory Cell and Molecular Biology, vol. 48, no. 6, pp. 685-693, 2013. 


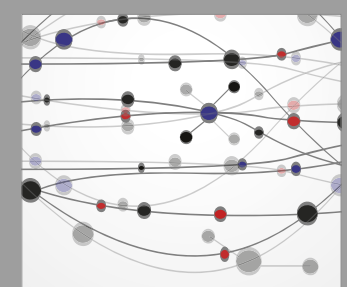

The Scientific World Journal
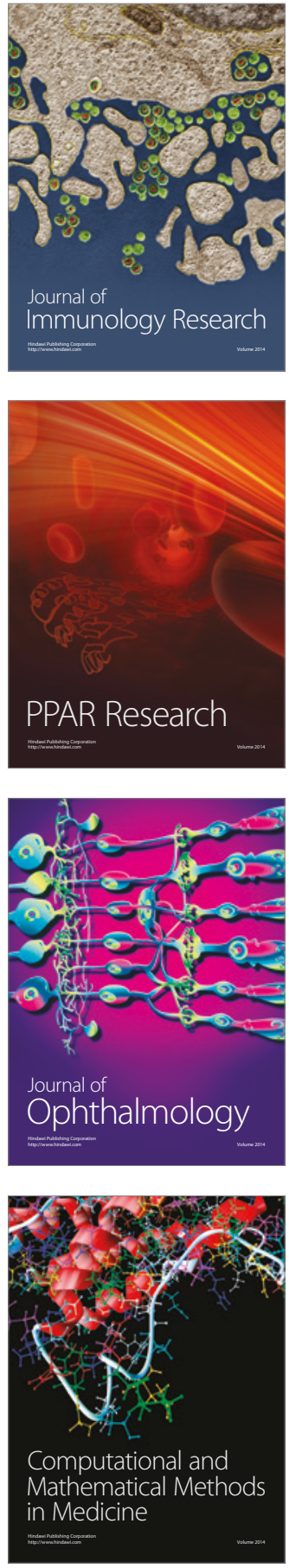

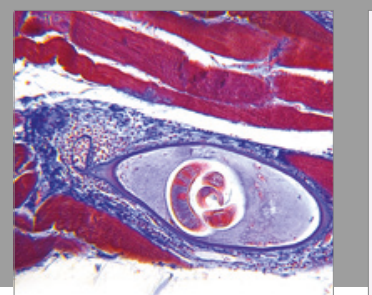

Gastroenterology Research and Practice
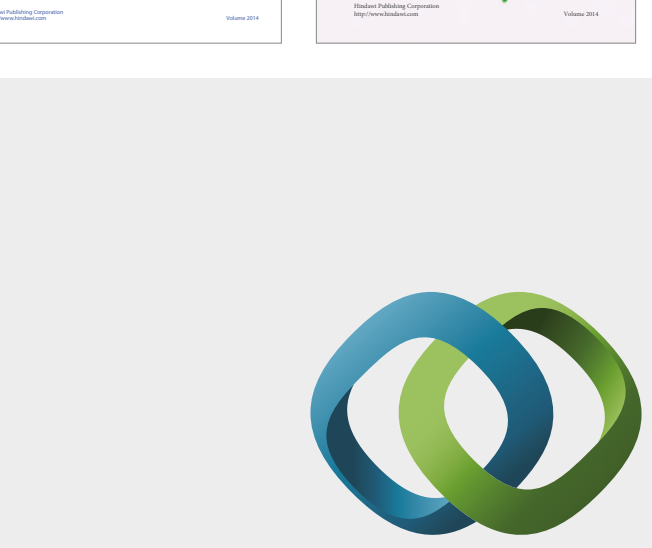

\section{Hindawi}

Submit your manuscripts at

https://www.hindawi.com
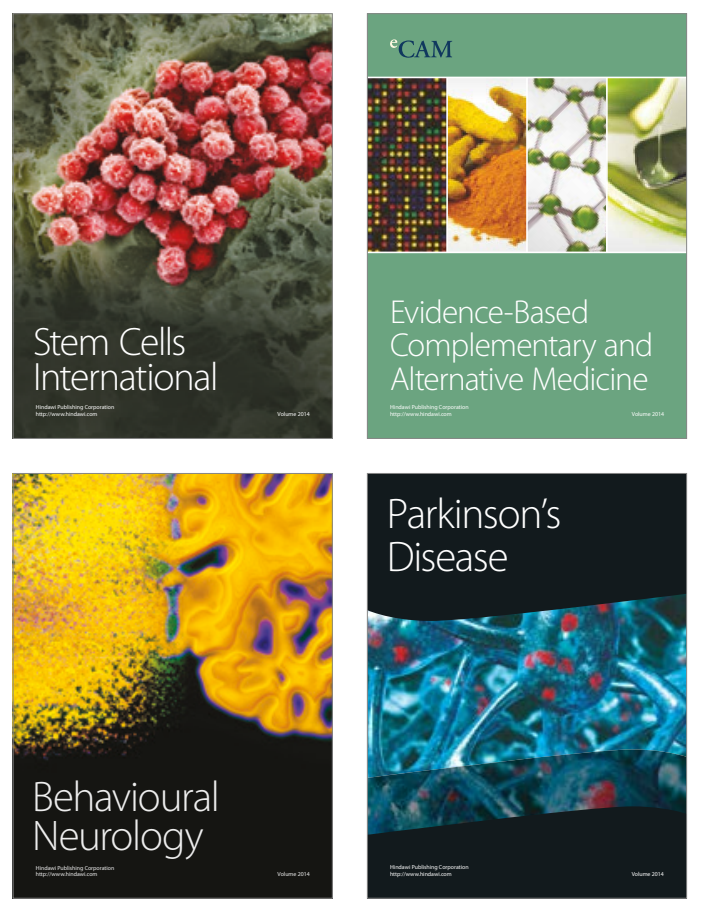
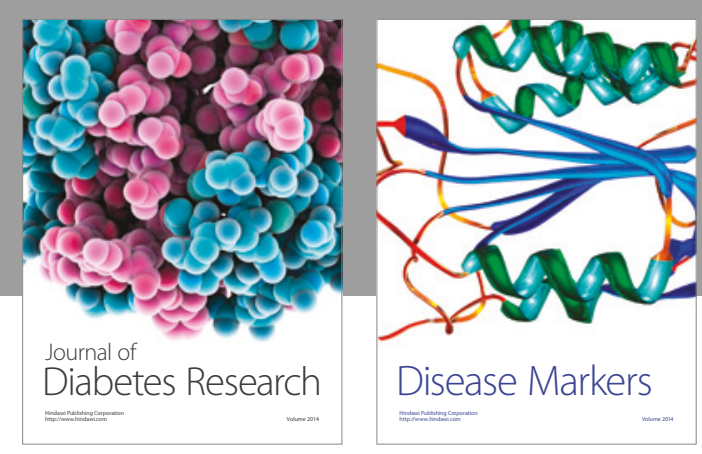

Disease Markers
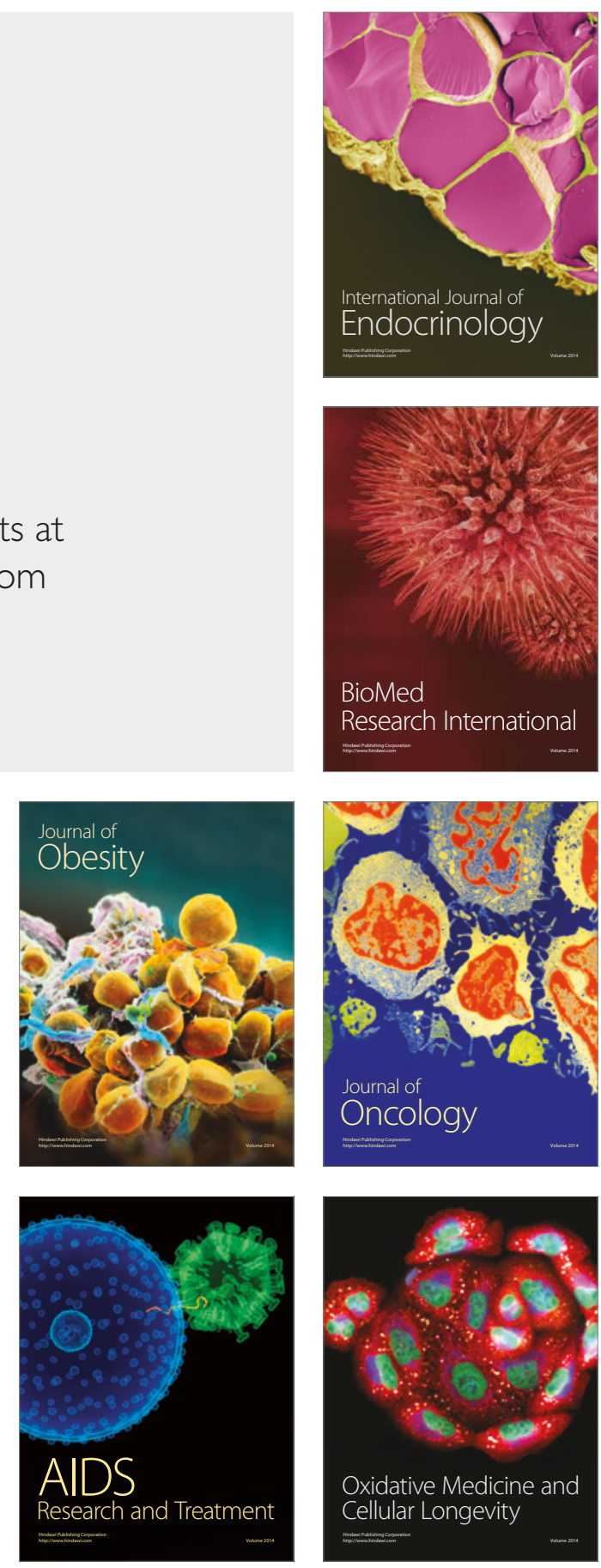